\title{
Strategic Plan Development for the Implementation of Balanced Scorecard as a Performance Measuring Instrument at Gotong Royong Hospital Surabaya
}

\author{
Indah Puji Lestari ${ }^{1}$, Nur Fadjrih Asyik ${ }^{2}$, Titik Mildawati ${ }^{3}$ \\ ${ }^{1,2,3}$ Sekolah Tinggi Ilmu Ekonomi Indonesia (STIESIA), Surabaya, Indonesia \\ phujieindah87@gmail.com
}

\begin{abstract}
This study aims to determine the development of a strategic plan from the evaluation results of implementing the balanced scorecard as a performance measurement tool at the Gotong Royong Hospital, Surabaya. This type of research uses descriptive qualitative. This data collection technique is carried out through (1) Interview (2) Documentation. The data source of this research from primary data. The analysis of the application of the balanced scorecard is to find out how the company is performing, then identify the internal and external environment to determine the key factors. After obtaining the key factors, they are evaluated using the EFE Matrix, IFE Matrix, TOWS Matrix, and IE Matrix, which is then obtained the recommended alternative strategies. The results of the recommended priority strategy alternatives are assessed using QSPM Matrix. The results Analysis using the EFE Matrix, IFE Matrix, TOWS Matrix, IE Matrix and QSPM then obtained the chosen strategy, namely product development and market penetration strategies. Based on the TOWS analysis, the reserachers provide recommendations that can be used to strengthen the strengths and opportunities as well as control weaknesses and threats by developing 13 strategies chosen.
\end{abstract}

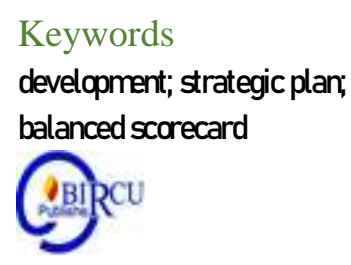

\section{Introduction}

The development of business, science and technology runs so quick, between institutions or organizations compete with each other and make changes and innovations to maintain the existence in the business world. According to Kotler et al. (2014) if the company wants to compete in the global market, one of them is to commit to creating and retaining customers and must be able to adapt to the changing market, by carrying out market-oriented strategic planning. Strategic planning allows companies to anticipate everchanging conditions, and provides a map of the journey and direction to go and how to achieve it (Jauch and Glueck, 2004).

The implementation of National Health Insurance $(\mathrm{JKN})$ that has been established by the government starting from January 1, 2014, hospitals in Indonesia must continue to improve in order to remain the hospital of choice for people who need health services. This can be realized if all leaders and staff in the organization are committed to improving the grade and quality of its services on a continous basis.

Strategic plan is a series of activities aimed at obtaining the welfare of clarity of direction and objectives of an organization. Gotong Royong Hospital has a strategic plan for the period 2016-2020 with strategic direction and proritas at Gotong Royong Hospital that is to realize quality health services through mutual care that aims to improve optimal, orderly, comfortable hospital health services by always paying attention 
to good quality and performance and respect the social values of professionalism and ethics so that the vision and mission of Gotong Royong Hospital can be fulfilled.

Balanced scorecard is a system mechanism that is able to translate the vision and strategy of the organization into real actions in the field. The implementation of balanced scorecard is very appropriate to be applied by non-profit organizations, because the measurement of the performance of non-profit organizations is not only financially centered but non-financial aspects are also the most important aspects. Through the evaluation of the implementation of balanced scorecards as a performance measuring instrument and the development of strategic plans, hospitals are expected to be able to provide quality services and provide satisfaction for those who use these services.

Some previous researches have done a lot of research on balanced scorecards. Such research done by Handayani (2011), Dewi (2014), Pamungkas (2014), Hadiyati (2014), Widhiyaningrat (2015). While research on the development of strategic plans such as research by Fahrianeta (2008) who compiled the development of strategic plans using the formulation of IFE Matrix and EFE Matrix and for alternative strategies using QSPM Matrix. Karmawan (2016) made strategic plan development by doing SWOT analysis and for decision making using Concensus Decision Making Group (CDMG) method. Aji and Tjahjono (2016) in their research analyzed the implementation of strategic plan using SWOT analysis, then the research by Lasyera et al. (2018) conducted research by analyzing strategic plans using IE Matrik.

The overview of the current performance of Gotong Royong Hospital has obtained the first accreditation status with class D hospital classification that has been established in November 2016 with a type of medical services consisting of 24-hour Emergency Services, Outpatient Services, Inpatient Services, Maternal Services, Operating Room Services (OK) and ICU Services, for supporting services consists of Laboratory Services, Radiology Services, Pharmacy Services, Nutrition Services, Medical Record Services and Instrument Sterilization Services, while for public services consists of Laundry, Maintenance facilities and medical and non-medical equipment, Waste Management, Environmental Sanitation, as well as procurement of Ambulances, Medical Gas Management and Clean Water Reservoirs.

Medical record data at Gotong Royong Hospital currently shows the presence of patient visits from various regions in Surabaya. The number of patient visits in 2016-2018, can be seen from the chart below.

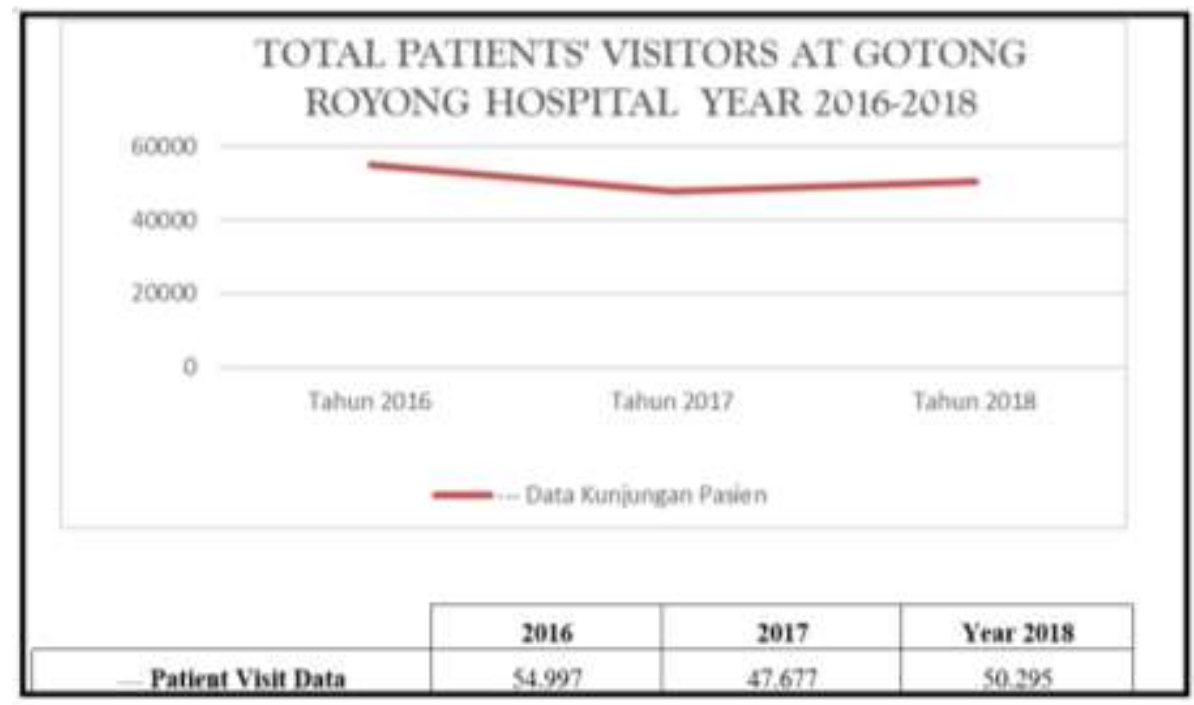

Source: Medical Record Data of Gotong Royong Hospital

Figure 1. Patient Visit Data of Gotong Royong Hospital 
The performance of service aspects at Gotong Royong Hospital can be seen from patient visit data in 2016-2018. From the medical record of patient visits, it is known that there has been a decrease in patient visits from 2016-2018. Based on current data to support its services Gotong Royong Hospital has emergency facilities, outpatient units that have 18 mpolyclinics, 37 inpatient rooms with 69 bed, maternity rooms, OK (operating rooms), medical check-ups, and equipped with ambulances. The number of Gotong Royong Hospital staff as many as 177 people consisting of 41 medical personnel, 63 nursing personnel, 37 medical support people and non-medical personnel as many as 35 people.

On the other side, data from BPS Surabaya, there are various health services centers consisting of 38 hospitals, 14 maternity place, 3 eye hospitals, 1 mental hospital, 1 cancer hospital, 1 surgical hospital, 1 internal disease hospital, 62 health centers, 69 medical laboratories, 99 optics, 762 pharmacies, and 59 herb stores.

This study aims to establish development of strategy plan from evaluation result implementation of balanced scorecard as a performance measuring instrument at Gotong Royong Hospital Surabaya. From several previous studies, data analysis of physical facilities, existing human resources, patient arrival data, and health care facilities in Surabaya, researchers made strategic plan development through the implementation of balanced scorecards as a performance measuring tool and can establish the development of a strategy plan in order to be an input for the Leadership of Gotong Royong Hospital related to the technical development of stategis plans that can be implemented into the activities of Gotong Royong hospital in accordance with its long-term goals.

\section{Research Methods}

This type of research uses interpretive paradigm with qualitative approach. The data source used in this study comes from the primary data, that is: data obtained directly from the source. The research subjects or respondents in this study are people who are seen as involved in planning the hospital's business strategy or can provide input for the development of the hospital's business strategy plan. The data source is obtained through direct observation with Interview / Indept Interview with related parts that is: Director of Gotong Royong Hospital Surabaya, Head of Marketing, Guarantor, SIR, General Vice Director Vice, Finance Vice Director, Head of HR Department, as well as requests for necessary documents include medical record data, financial statements and others.

\section{Results and Discussion}

Evaluation of the Implementation of Balanced Scorecard as a Performance Measuring Tool

\subsection{Financial Perspective}

a. Revenue Growth

Table 1. Income growth ratio of gotong royong hospital Year 2016-2018

\begin{tabular}{llll}
\hline Description & \multicolumn{3}{c}{ Years } \\
\cline { 2 - 4 } & $\mathbf{2 0 1 6}$ & $\mathbf{2 0 1 7}$ & $\mathbf{2 0 1 8}$ \\
\hline Revenue Realization & 12.161 .302 .200 & 10.815 .265 .000 & 12.036 .228 .000 \\
Growth Ratio & $50.38 \%$ & $-11.07 \%$ & $11.29 \%$ \\
\hline
\end{tabular}

Source: Data processed by the autho 
From the ratio results showed that Gotong Royong Hospital experienced a decrease in revenue in 2017, this decrease in revenue resulted from the tiered referral system of the BPJS health referring to Permenkes No. 56 Year 2014 and regulations on referral regionalization that greatly impacted the decrease in patient visits which greatly affected income. In 2018, Gotong Royong Hospital experienced an increase in revenue. This shows that revenue growth at Gotong Royong Hospital has been good despite the decline in revenue but can increase again.

\section{b. Cost Changes}

Table 2. Cost change ratio of Gotong Royong hospital Year 2016-2018

\begin{tabular}{llll}
\hline Description & \multicolumn{3}{c}{ Years } \\
\cline { 2 - 4 } & $\mathbf{2 0 1 6}$ & $\mathbf{2 0 1 7}$ & $\mathbf{2 0 1 8}$ \\
\hline Cost Realization & 12.095 .007 .300 & 10.588 .850 .500 & 12.905 .466 .000 \\
Cost Change Ratio & $50.72 \%$ & $-12.45 \%$ & $21.88 \%$ \\
\hline
\end{tabular}

Source: Data processed by the author

From the results of the ratio above shows that Gotong Royong Hospital experienced a decrease in costs in 2017 and while in 2018 again experienced an increase in costs. This shows that in 2017 Gotong Royong Hospital is able to reduce unnecessary expenditures, while in 2018 there is an increase in costs because Gotong Royong Hospital is still doing several stages of development. The results of the ratio of revenue growth and cost changes show that the performance of hospitals in terms of financial perspective is relatively good.

\subsection{Perspective}

\section{a. Customer Satisfaction}

There has been no customer survey in 2016-2018 by Gotong Royong Hospital Surabaya.

\section{b. Customer Accuisition}

Table 3. Measurement of customer acquisition at Gotong Royong Hospital Year

\begin{tabular}{cccc}
\multicolumn{3}{c}{$2016-2018$} \\
\hline Years & Number of Patients & New Patients & Retenstion \\
\hline 2016 & 54.997 & 18.951 & $34.46 \%$ \\
2017 & 47.677 & 17.561 & $36.83 \%$ \\
2018 & 50.295 & 10.425 & $20.72 \%$ \\
\hline
\end{tabular}

Source: Data processed by the author

From the measurement results showed that Gotong Royong Hospital experienced a decrease in customer acquisition and the number of new patients from year to year decreased. The decrease in the number of patients is due to the existence of jamkesmas program in the form BPJS health with regulation No. 1 of 2017 on reference regionalization. This resulted in Gotong Royong Hospital not being able to get new customers. 


\section{c. Customer Retention}

Table 4. Customer retention measurement of gotong royong hospital Year 2016-2018

\begin{tabular}{llll}
\hline Years & Number of Patients & Old Patients & Retention \\
\hline 2016 & 54.997 & 36.046 & $65.54 \%$ \\
2017 & 47.677 & 30.116 & $63.17 \%$ \\
2018 & 50.295 & 28.927 & $57.51 \%$ \\
\hline
\end{tabular}

Source: Data processed by the author

From the measurement results showed that Gotong Royong Hospital experienced a decrease in customer retention every year and the number of old patients also decreased from year to year. The decrease in the number of patients is also due to the "jamkesmas program" that is health BPJS which regulates regionalization and reference. This shows that Gotong Royong Hospital has not been able to maintain its customers.

\subsection{Internal Business Process Perspective}

a. BOR (Bed Occopancy Rate)

Table 5. Average BOR Value

\begin{tabular}{llllll}
\hline Years & $\mathbf{2 0 1 6}$ & $\mathbf{2 0 1 7}$ & $\mathbf{2 0 1 8}$ & Average & Ideal Standard \\
\hline BOR & $32.92 \%$ & $28.0 \%$ & $28.9 \%$ & $29.94 \%$ & $60-85 \%$ \\
\hline
\end{tabular}

Source: Data processed by the author

Based on the number of beds needs in accordance with BOR calculation standards, the ideal standard is $60-85 \%$ but the percentage of BOR at Gotong Royong Hospital is only $29.94 \%$ below the ideal standard. From the results showed that Gotong Royong Hospital has not been able the ideal standard of bed use.

\section{b. ALOS (Average Length of Stay}

Table 6. Average ALOS Values

\begin{tabular}{llllll}
\hline Years & $\mathbf{2 0 1 6}$ & $\mathbf{2 0 1 7}$ & $\mathbf{2 0 1 8}$ & Average & Ideal Standard \\
\hline ALOS & 2.90 & 2.90 & 2.90 & 2.90 & 6-9 days \\
\hline
\end{tabular}

Source: Data processed by the author

From the results showed the ALOS value at Gotong Royong Hospital is outside the ideal standard of 2.90 while the ideal standard is 6-9 days.

\section{c. TOI (Turn Over Interval)}

Table 7. Average TOI Value

\begin{tabular}{llllll}
\hline Years & $\mathbf{2 0 1 6}$ & $\mathbf{2 0 1 7}$ & $\mathbf{2 0 1 8}$ & Average & Ideal Standard \\
\hline TOI & 8.5 & 10.9 & 14.3 & 11.2 & $1-3$ days \\
\hline
\end{tabular}

Source: Data processed by the author

From the results showed that the average TOI value at Gotong Royong Hospital is 11.2 and has not reached the ideal standard value because it is still above 1-3 days while the ideal standard is in the range of 1-3 days. 
Table 8. Average BTO Value

\begin{tabular}{llllll}
\hline Years & $\mathbf{2 0 1 6}$ & $\mathbf{2 0 1 7}$ & $\mathbf{2 0 1 8}$ & Average & Ideal Standard \\
\hline BTO & 28.60 & 24.00 & 30.00 & 27.53 & $40-50$ times \\
\hline
\end{tabular}

Source: Data processed by the author

From the results showed that the average BTO value of Gotong Royong Hospital did not reach the ideal standard of 27.53 while the ideal standard specified was 40-50 times.

e. GDR (Gross Death Rate)

Table 9. Average GDR Value

\begin{tabular}{llllll}
\hline Years & $\mathbf{2 0 1 6}$ & $\mathbf{2 0 1 7}$ & $\mathbf{2 0 1 8}$ & Average & Ideal Standard \\
\hline GDR & 0.01 & 15,80 & 17 & 32.81 & $<45$ per 1000 patients out. \\
\hline
\end{tabular}

Source: Data processed by the author

From the results showed that the GDR value of Gotong Royong Hospital reached the ideal standard of 32.81 it was declared good and met the ideal standard determined that is $<45$ per 1000 patients out.

\section{f. NDR (Net Death Rate)}

Table 10. Average NDR Value

\begin{tabular}{llllll}
\hline Years & $\mathbf{2 0 1 6}$ & $\mathbf{2 0 1 7}$ & $\mathbf{2 0 1 8}$ & Average & Ideal Standard \\
\hline NDR & 0.01 & 26.4 & 7 & 11.14 & $<25$ per 1000 patients out. \\
\hline
\end{tabular}

Source: Data processed by the author

The results showed that the NDR value at Gotong Royong Hospital achieved an ideal value of 11.14 declared good the ideal standard of ranging $<25$ per 1000 patients out.

\subsection{Learning and Growth Perspectives} benchmarks:

Measurement through learning and growth perspectives using the following

\section{a. Employee Retention}

Table 11. Employee retention of Gotong Royong Hospital Surabaya Year 2016-2018

\begin{tabular}{lll}
\hline Years & Number of Employees & Employee Retention \\
\hline 2016 & 147 & $105.00 \%$ \\
2017 & 163 & $110.88 \%$ \\
2018 & 176 & $107.98 \%$ \\
\hline
\end{tabular}

Source: Data processed by the author

From the measurement results showed that the increase in employee commitment has been good this can be seen from the percentage of employee retention at Gotong Royong Hospital above $100 \%$ and the number of employees increased from year to year. This proves that Gotong Royong Hospital has been good at maintaining the number of employees. 


\section{b. Employee Training}

Table 12. Capability of employees of Gotong Royong Hospital Year 2016-2018

\begin{tabular}{lll}
\hline Years & Employee Training & Employee Capabilities \\
\hline 2016 & 51 & $35 \%$ \\
2017 & 29 & $18 \%$ \\
2018 & 26 & $15 \%$ \\
\hline
\end{tabular}

Source: Data processed by the author

From the measurement results showed that Gotong Royong Hospital experienced a decrease in employee capability every year and the number of employee training also decreased from year to year. The results of employee retention and training measurement show that the hospital's performance in terms of learning and growth perspective is quite good, this can be seen from the percentage of customer retention is above $100 \%$ even though the capability of employees has decreased.

\subsection{Opportunities and Threats}

After identifying internal factors for macro environmental data, an inventory of these variables and critical factors are opportunities and threats for Gotong Royong Hospital using Concencus Decision Making Group (CDMG). The consensus results are summarized in the Table as follows:

Table 13. External Factor Analysis of Gotong Royong Hospital

\begin{tabular}{|c|c|c|}
\hline Variable & Critical Success Factor & $\begin{array}{l}\text { Opportunities/ } \\
\text { Threat }\end{array}$ \\
\hline Government Policy & Government Support & Opportunities \\
\hline Demographics & Growing population & Opportunities \\
\hline Economic & Rising people's incomes & Threat \\
\hline Geography & $\begin{array}{l}\text { The location of Gotong Royong Hospital } \\
\text { is easy to reach }\end{array}$ & Opportunities \\
\hline Education & Population education rate increases & Threat \\
\hline Supplier & Have a good relationship with suppliers & Opportunities \\
\hline Competitors & $\begin{array}{l}\text { Availability of hospitals / other health care } \\
\text { facilities as competitors }\end{array}$ & Threat \\
\hline Customers & Decreased patient loyalty & Threat \\
\hline
\end{tabular}

Source: Data processed by the author

From the table above, it appears that variables are opportunities include government policy, demographics, geography and suppliers, while variables that are the threat of Gotong Royong Hospital are economic variables, education, competitors and customers. Based on existing critical factors, key factors are determined for each variable based on the opportunity and threat factors. 


\subsection{External Factor Evaluation (EFE) Matrix}

Table 14. External Factor Evaluation (EFE) Matrix

\begin{tabular}{lllll}
\hline oo & External Factors & Weights & Rating & W x R \\
\hline $\mathbf{A}$ & OPPORTUNITIES & 0,14 & 4 & 0,56 \\
1 & Government support for Gotong Royong Hospital & 0,1 & 2 & 0,2 \\
2 & Increasing population of Surabaya & 0,14 & 4 & 0,56 \\
3 & The location of Gotong Royong Hospital is easy to reach & 0,14 & 4 & 0,56 \\
4 & $\begin{array}{l}\text { GotongRoyong Hospital has a good relationship with } \\
\text { supplieers }\end{array}$ & $\mathbf{0 , 5 2}$ & $\mathbf{1 , 8 8}$ \\
& Total & & & \\
$\mathbf{B}$ & THREAT & 0,12 & 3 & 0,36 \\
1 & People's income in Surabaya increases & 0,1 & 2 & 0,2 \\
2 & Education of Surabaya residents increased & 0,12 & 3 & 0,36 \\
3 & $\begin{array}{l}\text { Availability of hospitals and other health care facilities as } \\
\text { competitors }\end{array}$ & 0,14 & 4 & 0,56 \\
4 & $\begin{array}{l}\text { Decreased patient loyalty } \\
\text { Total }\end{array}$ & $\mathbf{0 , 4 8}$ & $\mathbf{1 , 4 8}$ \\
\hline & Total Opportunity and Threat Factors & $\mathbf{3 , 3 6}$ \\
\hline
\end{tabular}

Source: Data processed by the author

EFE Matrix results are used to summarize opportunities and threats to a business unit. From the results of EFE Matrix Analysis obtained an overview of the external condition of the company that the company's opportunities are greater than the threat.

\subsection{Strengths and Weaknesses}

Table. 15. Internal Factor Analysis of Gotong Royong Hospital

\begin{tabular}{|c|c|c|}
\hline Variable & Critical Success Factor & $\begin{array}{l}\text { Strengths/ } \\
\text { Weaknesses }\end{array}$ \\
\hline Vision and Mission & Vision and mission that are already relevant & Strength \\
\hline Organization & Has been accredited "Plenary" & Strength \\
\hline Tbsp & Sufficient number of medics and paramedics & Strength \\
\hline Service Products & The existence of 24 -hour service & Strength \\
\hline Physical Facilities & Some physical facilities need development & Weakness \\
\hline Marketing & Marketing tasks and functions not available & Weakness \\
\hline Financial & Financial performance is optimal & Strength \\
\hline Information System & Hospital management information system is optimal & Strength \\
\hline$R \& D$ & $\begin{array}{l}\text { Research and development of Gotong Royong Hospital } \\
\text { hasn't optimal }\end{array}$ & Weakness \\
\hline
\end{tabular}

Source: Data processed by the author

\subsection{Internal Factor Evaluation (IFE) Matrix}

Table 16. Internal Factor Evaluation (IFE) Matrix

\begin{tabular}{lllll}
\hline № & Internal Factors & Weights & Rating & W x R \\
\hline A & STRENGHTS & & & \\
1 & Vision and mission that are already relevant & 0,1 & 2 & 0,2 \\
2 & Has been accredited "Plenary" & 0,14 & 4 & 0,56 \\
3 & Sufficient number of medics and paramedics & 0,1 & 2 & 0,2 \\
4 & The existence of 24-Hour service & 0,1 & 2 & 0,2 \\
5 & Financial performance is optimal & 0,1 & 2 & 0,2 \\
6 & Hospital management information system is optimal & 0,1 & 2 & 0,2 \\
& Total & $\mathbf{0 , 6 4}$ & & $\mathbf{1 , 5 6}$
\end{tabular}




\section{B WEAKNESS}

$\begin{array}{lllll}1 & \text { Some physical facilities need development } & 0,14 & 4 & 0,56 \\ 2 & \text { Marketing tasks and functions not available } & 0,12 & 3 & 0,36 \\ 3 & \begin{array}{l}\text { Research and development of Gotong Royong } \\ \text { Hospital hasn't optimal }\end{array} & 0,1 & 2 & 0,2 \\ \begin{array}{l}\text { Total } \\ \text { Total Strength and Weakness Factors }\end{array} & \mathbf{0 , 3 6} & & \mathbf{1 , 1 2} \\ \end{array}$

Source: Data processed by the author

Matrix IFE results are used to summarize strengths and weaknesses in a business unit. From the results of the IFE Matrix Analysis obtained an overview of the internal condition of the company that the strength of the company is greater than the weakness.

\subsection{Matching Stage}

\section{Positioning}

\section{TOWS Matrix}

Positioning by using TOWS Matrix is by combining strength and weakness factors against opportunity and threat factors. At the input stage, the element of strength (1.56) is greater than the element of weakness (1.12) and the opportunity element (1.88) is greater than the threat (1.48). The position of the TOWS Matrix can be seen in the table below.

Table 17. TOWS Matrix

\begin{tabular}{lll}
\hline & \multicolumn{1}{c}{ List Internal Strengths } & List Internal Weaknesses \\
\hline List Internal & 4 & 2 \\
Opportunities & Future Quadran & \\
& $-\quad$ Related Diversification & \\
& $-\quad$ Vertical Integration & \\
& - Market Development & \\
& $-\quad$ Product Development & \\
& - Market Penetration & 1
\end{tabular}

Source: Data processed by the author

Thus, the results of the map in the TOWS Matrix show the position of Gotong Royong Hospital is in quadrant 4 (Future Quadran) that is, management must maximizing the srrenght they have and take advantage of external opportunities.

\section{Matrix IE}

In determining Matrix IE using the total score values EFE and IFE. The mapping result of the total EFE score is 3.36 and the total IFE score is 2.68. It shows the position of Gotong Royong Hospital in cells I and II in the picture below. 


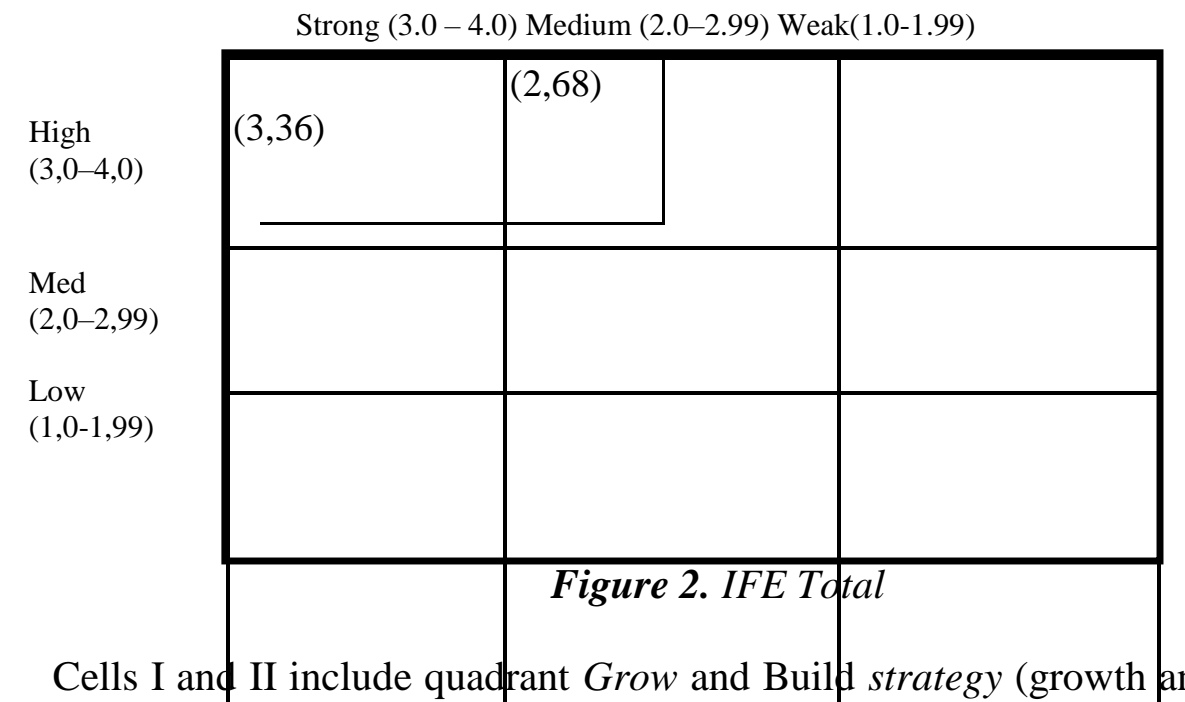

and the recommended strategies in these cells are intensive strategies. The first strategy is to find market share. The second strategy is market development. The third strategy is product development.

\subsection{Stages of Strategic Alternative Determination}

The results obtained at the matching stage using TOWS and IE Matrix resulted in several recommended alternative strategies, namely:

Table 18. Stage Matching

\begin{tabular}{lc}
\hline TOWS MATRIX & IE MATRIX \\
FUTURE QUADRAN & GROW AND BUILD \\
\hline -Related Diversification & -Market penetration \\
- Vertical Integration & -Product development \\
-Market Development & \\
-Product Development & \\
-Market Penetration & \\
\hline
\end{tabular}

Source: Data processed by the author

From the table, it shows that the strategies selected and represented by the two existing matrix are product development and market penetration strategies. From the above results can be developed with increased product and market penetration. Both strategies can be used as input to the Gotong Royong Hospital to improve its performance.

\subsection{TOWS Analysis}

The results of TOWS analysis from internal and external analysis are the following.

Table 19. TOWS Analysis

\begin{tabular}{ll}
\hline STRENGTH $(\mathbf{S})$ & WEAKNESS(W) \\
\hline 1. Vision and mission that & $\begin{array}{l}\text { 1.Some physical facilities need } \\
\text { are already relevant }\end{array}$ \\
$\begin{array}{ll}\text { 2. Has been accredited } \\
\text { "Plenary" }\end{array}$ \\
$\begin{array}{l}\text { 2. Marketing tasks and functions } \\
\text { not available }\end{array}$ \\
medics and paramedics of & $\begin{array}{l}\text { 3.Research and development of } \\
\text { Gotong Royong Hospital } \\
\text { 4. The existence of 24-Hour hasn't optimal }\end{array}$ \\
\hline
\end{tabular}


service

5. Financial performance is optimal

6. Hospital management information system is optimal

\section{OPPORTUNITY $(\mathrm{O})$}

1. Government support for Gotong Royong Hospital

2. Increasing population of Surabaya

3. The location of Gotong Royong Hospital is easy to reach

4. Gotong Royong Hospital has good relations with suppliers

\section{STRATEGY (SO)}

1. Creating Governance of hospital

2. Making Geriatric Services as Excellent Service

3. Improvement of human resources both in terms of quality and quantity is customized to the needs of

4. Optimizing networking systems and partnerships with suppliers

\section{STRATEGY (WO)}

Good 1. Realizing hospital class into class C or B

2. Improvement of Outpatient Services both in terms of service and service hours

3. Building educational effectiveness and excellent research centers

\begin{tabular}{|c|c|c|}
\hline THREAT (T) & $Y(S T)$ & $Y(W T)$ \\
\hline People's & 1 Measure & $1 . \mathrm{Pl}$ \\
\hline incre & $\mathrm{v}$ & $\mathrm{De}$ \\
\hline $\begin{array}{l}\text { on of } \mathrm{S} \\
\text { s increased }\end{array}$ & $\begin{array}{l}\text { nnaires every year. } \\
\text { e hospital revenue }\end{array}$ & $\begin{array}{l}\text { iting the marketing } \\
\text { on }\end{array}$ \\
\hline $\begin{array}{l}\text { 3. Availability of hospitals and } \\
\text { other health care facilities as } \\
\text { competitors in Surabaya }\end{array}$ & $\begin{array}{l}\text { 3. Create an MOU with } \\
\text { private insurance, private } \\
\text { clinics, schools and }\end{array}$ & $\begin{array}{l}\text { 3.Optimizing the research and } \\
\text { development of Gotong } \\
\text { Royong Hospital by making it }\end{array}$ \\
\hline De & & $\begin{array}{l}\text { as the } \\
\text { Hospital. }\end{array}$ \\
\hline
\end{tabular}

Source: Data processed by the author.

\section{Conclusion}

From the results of the study, the results of performance achievement analysis on the application of balanced scorecards from 4 perspectives showed:

\subsection{Hospital Performance from a Financial Perspective}

Performance from a financial perspective is rather good, for the revenue growth of Gotong Royong Hospital has been good while for the change in costs Gotong Royong Hospital has not been able to reduce unnecessary expenditures, this is because until now Gotong Royong Hospital is still doing several stages of development.

\subsection{Performance from a Customer Perspective}

Measurement performance from a customer perspective shows the performance of hospitals in terms of customer perspective is classified not so good because of the decrease in the percentage of the number of acquisitions and retention of customers, the results of customer acquisition performance achievements gotong Royong Hospital has not been able to acquire the number of customers this is due to the "jamkesmas program" that is reference regulations for BPJS health patients. For the measurement of customer satisfaction is still not good, because from the Hospital Gotong Royong has never been held a customer satisfaction survey, so they don't have measurement of customer satisfaction, the performance of customer retention also shows that Gotong Royong 
Hospital experienced a decrease in customer retention every year and the number of old patients also decreased, the decrease in customer retention is also due to BPJS health regulations.

\subsection{Performance from an Internal Business Process Perspective}

From some measurements of the effectiveness of hospital services shows that the performance of hospitals in terms of internal business process perspective is classified less good. Some indicators don't reach standards are: BOR, ALOS, TOI and BTO, while for GDR and NRD already reach standards.

\subsection{Performance in Terms of Learning and Growth}

The results of measurement of employee retention and training showed that the hospital's performance in terms of learning and growth perspective is rather good, this can be seen from the percentage of customer retention is above $100 \%$ although for the capability of employees decreased, for the decrease in employee capability is expected Gotong Royong Hospital to continue to improve the development of the quality of health services and human resources owned by adding training for employees to improve employee performance in the future.

After knowing the results of performance analysis on the implementation of balanced scorecard can be known in terms of customer perspective and internal business process perspective at Gotong Royong Hospital there needs to be a development of strategy plan.

The results of developing a strategyc plan at Gotong Royong Hospital from the analysis external environment and the internal environment by conducting Consensus DecisionnMaking Group (CDMG), and by using IFE Matrix and EFE Matrix known the ability of Gotong Royong Hospital that is a greater strength than weaknesses and opportunities of hospitals greater than threats. By using TOWS Matrix, the position of Gotong Royong Hospital is in the 4th quadrant namely Future Quadran while with IE Matrix in Cells I and II is included in the Grow and Build strategy. After matching stage in both matrix obtained alternative strategies arenproduct development and market penetration.

The development of the strategy plan from the results of the TOWS Analysis obtained several proposals for the development of strategic plans on strengths, opportunities, weaknesses and threats, namely:

\subsection{Strategy (SO)}

a. Creating good governance hospital, in accordance with the Hospital Law to create good governance hospitals must have an effective, efficient and accountable organization in accordance with UU Article 33 paragraph (1) UU No. 44/2009 and Article 36 of UU No. 44/2009

b. Making Geriatric Services as a superior service by improving services in the field of geriatric services.

c. Improving human resources both in terms of quality and quantity, increasing the professionalism of human resources both medical, medical and administrative with the trainings $\mathrm{n}$ customized to the needs of hospitals.

d. Optimizing networking systems and partnerships with suppliers, managing good relationships with suppliers who frequently interact with hospitals. Effective communication with suppliers will make inventory management better and improve the overall process of acquisition of goods. 


\subsection{Strategy (ST)}

a. Measure customer satisfaction by creating questionnaires every year.

b. Increasing hospital revenues by improving the quality of services, facilities and infrastructure and promoting hospitals to be better known to the public.

c. Create MOU / cooperation agreement with private insurance, private clinics, schools and companies to increase hospital revenue.

\subsection{Strategy (WO)}

a. Realizing the hospital class into class $\mathrm{C}$ or B by participating in hospital accreditation.

b. Improvement of Outpatient Services both in terms of service and service hours, improvement of outpatient services in terms of services can be supported by the timeliness of services, services in accordance with procedures and standards (SOP), implementation of zero error, completing number of human resources and supporting facilities.

c. Building the effectiveness of education and excellent research centers by cooperation with educational institutions and realizing as an educational hospital.

\subsection{Strategy (WT)}

a. Development of Physical Facilities with the addition of several building constructions to support hospital services.

b. Recruiting the marketing department by finding employees who are competent marketing in their sector and held training as needed.

c. Optimizing research and development of Gotong Royong Hospital by making it as the Main Education Hospital, by cooperating with educational institutions and playing a role in conducting research and development of research and society service continously.

\subsection{Suggestions}

Based on the conclusion, the recommended strategy reformulation to be done is market penetration, and product development. In implementing the strategy, the things needed by Gotong Royong Hospital in achieving growth goals, researchers suggest:

1. Strategy development of strengths and opportunities

a) Creating Governance Creates Good Hospital Governance;

b) Making Geriatric Services as Excellent Services;

c) Human resource improvement both in terms of quality and quantity customized needs. To improve the quality of human resources by providing opportunities to attend trainings and work shops and evaluations of the training activities;

d) Optimizing networking systems and partnerships with suppliers

2. Strategy development of strengths and threats

a) Measure customer satisfaction by making questionnaires on patient satisfaction. To improve the quality of hospital services and customer satisfaction the author recommends that the gotong royong hospital customer satisfaction survey be held from year to year;

b) Increase hospital revenue;

c) Create an MOU with private insurance, private clinics, schools and companies

3. Strategy development of opportunities and weaknesses

a) Realizing the hospital class into class $\mathrm{C}$ or B,

b) Improvement of Outpatient Services both in terms of service and service hours; 
c) The development of physical facilities, it is necessary for the management to make an annual work program or bussines plan of Gotong Royong Hospital from a choice of strategies;

d) Building educational effectiveness and excellent research centers

4. Developing strategies for weaknesses and threats

a) Development of physical facilities (operating rooms, ICU and parking facilities);

b) Recruiting marketing. By recruiting employees in the field of marketing or marketing is expected to increase revenue from The Gotong Royong Hospital to increase and hold regular meetings to evaluate the implementation of hospital marketing;

c) Optimizing the research and development of Gotong Royong Hospital by making it as the Main Education Hospital.

\section{References}

Aji, A.P., dan H.K. Tjahjono. 2016. Pemahaman Implementasi Rencana Strategi Bisnis Rumah Sakit PKU Muhammadiyah Petanahan. Jurnal Medicoeticolegal dan Manajemen Rumah Sakit 5(2): 93-106.

Dewi, N. 2014. Penilaian Kinerja Berdasarkan Keuangan Dan Non Keuangan Rumah Sakit Umum Daerah Wangaya. E-Jurnal Akuntansi Universitas Udayana 7(3): 761-777.

Fahrianeta. 2008. Pengembangan Rencana Strategis Rumah Sakit Tugu Ibu Tahun 20082012. Tesis. Universitas Indonesia.

Hadiyati, N. 2014. Pengukuran Kinerja dengan Metode Balanced Scorecard (Studi Empiris pada Rumah Sakit PKU Muhammadiyah Delanggu Klaten). Skripsi. Universitas Muhammadiyah. Surakarta.

Handayani, B. 2011. Pengukuran Kinerja Organisasi Dengan Pendekatan Balanced Scorecard Pada RSUD Kabupaten Kebumen. Jurnal Dinamika Manajemen 2(1): 7891.

Jauch, L. R., dan W. F. Glueck. 2004. Strategic Management and Business Policy (9th Ed). New York: McGraw-Hill.

Kaplan, R. S., dan D. Norton. 2001. The Strategy Focused Organization: How Balanced Scorecard Companies Thrives in The New Business Environment. Boston: Harvard Business School Press.

.2007. Using The Balanced Scorecard As A Strategic Management System. Boston: Harvard Business Review.

2011. The Balanced Scorecard: Strategy Into Action. Boston: Harvard Business School Press.

Karmawan, B. 2016. Penyusunan Rencana Strategis Rumah Sakit Pertamina Jaya Tahun 2017-2022. Jurnal Administrasi Rumah Sakit 2(2): 115-126

Kurniawan, A., T. Lestari dan Rohmadi. 2010. Analisis Pemanfaatan Data Sensus Harian Rawat Inap Untuk Pelaporan Indikator Pelayanan Rawat Inap Di Rumah Sakit Umum Daerah Dr. Soeroto Ngawi. Jurnal Kesehatan 4(2): 62-86.

Kotler, Philip., A. Gary. 2014. Principles of Marketing (10th Ed). New Jersey: Prentice Hall.

Lasyera, E., Y.H. Yeni, H. Busuddin. 2018. Analisis Rencana Strategi Rumah Sakit Umum Daerah Arosuka Kabupaten Solok. Jurnal Kesehatan Adalas 7(2): 170-175.

Pamungkas, C.E. 2014. Pengukuran Kinerja Dengan Elemen-Elemen Balance Scorecard (Studi Kasus Empiris RSUD Sukoharjo). Skripsi. Universitas Muhammadiyah. Surakarta. 
Rangkuti, F. 2014. Analisis SWOT Teknik Membedah Kasus Bisnis. Jakarta: PT. Gramedia Pustaka Utama.

Republik Indonesia, 2014a, Peraturan Menteri Kesehatan Republik Indonesia Nomor 56 Tahun 2014 tentang Klasifikasi dan Perizinan Rumah Sakit, Jakarta.

Republik Indonesia. 2009. Undang-Undang RI Nomor 44 Tahun 2009 tentang Rumah Sakit.

Siagian, S. 2005. Manajemen Stratejik. Edisi keenam. Jakarta: Bumi Aksara.

Trisnantoro, L. 2005. Aspek Strategis Manajemen Rumah Sakit. Yogyakarta: Andi.

Truitt, W.B. 2002. Business Planning: A Comprehensive Framework and Process. Quorum Books.

Widhiyaningrat, W. A. 2015. Pengukuran Kinerja Organisasi Nirlaba dari Perspektif Balanced Scorecard pada Rumah Sakit Umum Haji Surabaya. Jurnal Ilmu\&Riset Akuntansi 4(6):1-20. 